\title{
APPLICATION OF EISNER V. MACOMBER TO PRO RATA STOCK DISTRIBUTIONS IN PAYMENT OF SALARIES: AN OPPORTUNITY FOR TAX MANIPULATION*
}

The Internal Revenue Code permits a taxpayer corporation to deduct from its gross income reasonable compensation for services rendered to the corporation. ${ }^{1}$ Under the accrual basis of accounting, this deduction is taken in the year when the liability for salary accrues, even if no payment is made at that time. ${ }^{2}$ A method of payment frequently employed is the transfer to the employee of shares of stock in the corporation. ${ }^{3}$ The recipient must report as gross income the fair market value of the stock at the date of transfer." A cash basis employee reports income in the year of transfer, ${ }^{5}$ while an accrual basis employee reports income in the year when his salary claim against the corporation accrues. ${ }^{6}$

Under the rule of Eisner $v$. Macomber, ${ }^{7}$ applicable to distributions prior

*Deloss E. Daggitt, 23 T.C. No. 6 (Oct. 13, 1954).

1. Int. Rev. Code of $1939, \S 23$ (a) (1) (A), as amended, 56 Srıt. 819 (1942) (now INT. REv. CoDE of 1954, $\S 162$ (a) (1)). For general criteria of reasonableness, see U.S. Treas. Reg. 118, $\$ 39.23$ (a) -6 (1953) ; Commercial Iron Works Co. v. Commissioner, 166 F.2d 221 (5th Cir. 1948). Compensation to officers or stockholders which bears a close relation to stack interests is carefully scrutinized. See U.S. Treas. Reg. 118, § 39.23 (a)-6 (1953) ; J.J. Hart, Inc, 9 T.C. 135 (1947) ; Holmes \& Janes, Inc., 30 B.T.A. 74 (1934).

See, generaily, 1 Miertens, Federal Ixcose Taxation $\S 9.22$ (1942).

2. U.S. Treas. Reg. 118, $\S 39.43-1$ (1953); Lucas v. Ox Fibre Brush Co., 281 U.S. 115 (1930). Income is determined in accordance with the taxpayer's accounting method so long as this clearly reflects income. Int. Rev. Code of 1939, 8 41, 33 Star. 24 (now INT. REv. CODE of 1954, $\S 446$ ). Corporations will usually follow the acerual basis of accounting because their transactions are many and complex. 2 CCH 1955 Sravo. Febo. TAX REP. $\{2820.027$.

Year-end accruals of salaries and bonuses in years of large corparate incomes may be disallowed to prevent tax manipulation. C.S. Ferry \& Son, Inc, 18 B.T.A. 1261 (1930).

3. Cf. $1 \mathrm{CCH} 1955$ Stand. Fed. TAX Rep. $\{$ 646.103. See, e.g., Indianapolis Glove Co. v. United States, 96 F.2d 816 (7th Cir. 1938); United States Steel Curp., 2 T.C. 430 (1943). The corporation may deduct the fair market value of the stock, Packiage Miachinery Co., 2S B.T.A. 980 (1933), or the difference between the fair market value of the stock and the employee's subscription price, United States Steel Corp., supro.

Although a corporation's assets are not reduced by a distribution of its own stuck, this stock has always been considered sufficient payment to permit a deductiun, since the corporation can always sell the stock and realize the fair market value. See upiniuns in Commercial Investment Trust Corp., 28 B.T.A. 143 (1933).

4. U.S. Treas. Reg. 118, $\$$ 39.22(a) -3, -1 (1953); Allen v. Commissioner, 107 F.2d 151 (4th Cir. 1939).

5. U.S. Treas. Reg. 118, § 39.22(a)-3 (1953).

6. U.S. Treas. Reg. 118, § 39.43-1 (1953).

7. 252 U.S. 189 (1920). 
to the 1954 Code, ${ }^{8}$ a stockholder receiving a distribution of shares of stock in proportion to his holdings in the corporation realizes no taxable income

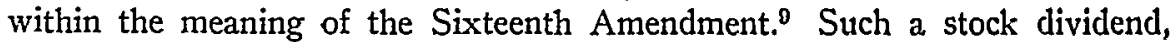
involving a transfer of corporate funds from undistributed surplus to capital, ${ }^{10}$ does not result in a severance of income from the capital assets of the corporation. ${ }^{11}$ And since it does not change the stockholder's "proportionate interest" in the corporation, it does not increase the intrinsic value of his holdings. ${ }^{12}$ Under the proportionate interest test stock distributions are taxable if they give the recipients a different interest in the corporation in terms of dividend, voting, or liquidation rights. ${ }^{13} \mathrm{But}$ it is clear that no income is realized in cases like Eisner v. Macomber involving distributions of common stock pro rata to existing holders of common stock. ${ }^{14}$

The recent case of Deloss E. Daggitt ${ }^{15}$ presented a unique situation in which stockholders received a pro rata distribution of stock as payment for services rendered to the corporation. Producers Transport, Inc., accrued in December 1947 , a $\$ 10,000$ salary liability for services performed in that year by its two principal stockholders, and deducted this expense from its 1947 income tax return. ${ }^{16}$ Of this amount, $\$ 9000$ constituted the 1947 salary of Daggitt, the president of the corporation, and $\$ 1000$ constituted additional compensation to Reid, its terminal manager. ${ }^{17}$ At the time these salaries were voted, the stockholders agreed to accept payment in stock of the corporation. ${ }^{18}$ In February 1948, Producers Transport settled the above liability account by authorizing and issuing to the employee-stockholders at par value 1000 additional shares of $\$ 10$ par common stock. ${ }^{10}$ Daggitt, holder of 90.84 per cent of the existing common stock, received 900 shares, while Reid, holder of 9.08 per cent, received 100 shares. $^{20}$ The corporation debited the

8. For changes made by the 1954 Code, see text at note 37 infra.

9. Eisner v. Macomber, 252 U.S. 189, 219 (1920).

10. Paton, Essentials of Accounting 737-42 (rev. ed. 1949); Ballantine, ColPORATIONS 481-85 (rev. ed. 1946).

11. Eisner v. Macomber, 252 U.S. 189, 210 (1920).

12. Id. at 211. Capitalization is the opposite of a realization, as the profits are placed in the capital stock account and no longer available for distribution. Ibicl.

13. Koshland v. Helvering, 298 U.S. 441 (1936) (dividend of voting common on non-voting preferred); Helvering v. Gowran, 302 U.S. 238 (1937) (dividend of preferred on common). See, generally, Lowndes, Taxation of Stock Dividends and Stock Rights, 96 U. PA. L. Rev. 147 (1.947).

14. Helvering v. Sprouse, 318 U.S. 604 (1943) (non-voting common on voting common). For a general discussion of the limitations on Eisner v. Macomber, 252 U.S. 189 (1920), see Magili, Taxable Incone 44-47, 58, 65-80 (rev. ed. 1945).

15. 23 T.C. No. 6 (Oct. 13, 1954).

16. Deloss E. Daggitt, 23 T.C. No. 6, at 2 (Oct. 13, 1954).

17. Ibid.

18. Ibid. The corporation's cash position was such that it could not make full payment in cash. Ibid.

19. Id. at 2-3.

20. Id. at 1-3. There were also two qualifying shares of stock outstanding. Id. at 1 . 
salaries payable account and credited the capital account, but did not capitalize surplus. ${ }^{21}$ Daggitt, deeming himself to be on the accrual basis, reported his salary as part of his gross income for 1947.22 Reid, a cash basis taxpayer, reported his additional compensation as income in 1948.23

The Commissioner determined deficiencies in the 1948 returns of both employees, contending that upon receipt of the stock, Daggitt and Reid had realized income to the extent of the fair market value of the stock- $\$ 58.75$ per share. ${ }^{24}$ The Tax Court held that the employees had received no constitutional income, since their "proportionate interests" in the corporation were "substantially" maintained by the stock distribution." Although it stated that the distribution was not a stock dividend, presumably because there had been no capitalization of surplus, the court found that Daggilt presented a situation "so close" to Eisner v. Macomber that it felt compelled to follow that case. ${ }^{26}$

The Tax Court could have reasoned that the stockholders constructively received payment in cash of their salary claims, ${ }^{2 \pi}$ and simultaneously sub-

21. Brief for Respondent, p. S, Deloss E. Daggitt, 23 T.C. No. 6 (Oct. 13, 1954). See note 36 infra.

22. Deloss E. Daggitt, 23 T.C. No. 6, at 3 (Oct. 13, 1954).

23. Ibid.

24. Ibid.

25. Id. at 3-4. The court held that the slight increase in Reid's proportionate interest was de minimis. Id. at 4.

Despite the fact that the shareholders received no income from the transaction, they might have felt that their interests were more flexible with additional shares of stoel:Moreover, they might have had the psychological motive of receiving something tangible for their services from a prosperous corporation which was investing its cash in eapital equipment. See Zang \& Thompson, Why Stock Dizidends Are Declored, 27 Taxes 883,885 (1949). But the shareholders could have achieved the same effect by means of a stock split.

26. Deloss E. Daggitt, 23 T.C. No. 6, at 3 (Oct. 13, 1954). The Commissioner has acquiesced in this decision. $4 \mathrm{P}-\mathrm{H} 1955 \mathrm{FED}$. TAX SERv. II 76743.

See also Benjamin Josephson, P-H 1947 T.C. Afem. Dec. If 47186 (stock as payment for accrued salaries to sole stockholder non-taxable under Eisner v. Macomber, 252 U.S. $189(1920))$.

27. I.T. 2277, V-1 Cuar. BuLL. 206 (1926) (officers' salaries credited by controlled corporation to purchase of capital stock were constructively received by officers); J.R. Holsey Sales Co., P-H 1945 T.C. Mem. Dec. If 45163 (stochholder constructively received income even though corporation's check paying for services was endorsed back: to corporation as capital contribution). Cf. James J. Cooney, 18 T.C. $8 \& 3$ (1952) (bonuses authorized to principal stockholder-officers of controlled corporation were constructively received although not set aside on corporate buoks). Lut ct. John Harvey Kellogg, 2 T.C. 1126 (1943) (constructive receipt rejected where stoclsholder gratuitously forgave salaries).

In Commissioner v. Capento Securities Corp., 140 F.2d 382 (1st Cir. 1944), the court held that substitution of stock for bonds in a reorganization amounted to a subseription for the stock in the amount of the bonded indebtedness. The bundholders must have constructively received the amount of the debt in order to subscritie for the stosk. But cf. Claridge Apartments Co. v. Commissioner, 138 F.2d 962 (7th Cir. 1943), reid on other grounds, 323 U.S. 141. (1944). 
scribed pro rata for the equivalent par value of additional stock in the corporation. ${ }^{28}$ Daggitt and Reid considered that they had received income, since they reported their salary claims. And Daggitt presented no problem of tax avoidance, since the salaries deducted by the corporation were included by its stockholders. ${ }^{29}$ If the proportionate interests of the stockholders had changed as a result of the salary accrual and stock distribution, the stockholders would have been taxable to the extent of the fair market value of the stock distributed. ${ }^{30}$ But since the stockholders' interests in Daggitt remained unchanged, Eisner v. Macomber would prevent their realization of any income except the salary constructively received. ${ }^{31}$

28. Eisner v. Macomber, 252 U.S. 189 (1920), has no application to a pro rata stock: subscription. There is no possibility of gain or loss either to the stockholder or the corporation from any form of stock subscription. U.S. Treas. Reg. 118, $\$ 39.22$ (a) -15 (1953). The stockholder receives as his basis the subscription price of the stock. Estate of L.W. Mallory, 27 B.T.A. 750 (1933). Under this theory, the basis in Daggitt would have been the accrued salary claim reported as income and with which the stock sulscription at par value was made, see text at note 19 supra, although in the case of a non-pro rata stock distribution in payment of salaries, the stockholder must report as income and receives as basis the fair market value of the stock. Commissioner v. Vandeveer, 114 F.2d 719 (6th Cir. 1940). In a pro rata stock dividend there is no basis for the stock distributed but the old basis is allocated between the old and now stack. Int. Rev. Code of 1939, § 113(a) (19), added by 53 Stat. 872 (1939) (now INT. Rev. Conk: of 1954, § 307). Since the Tax Court in Daggitt held that the stockholder-employees received no constitutional income in 1948, they apparently had no basis for the stock even though they reported the salaries as income. Although Reid might be able under Daggitt to reopen his 1948 return in order to get a refund of the tax paid on his reported salary, Daggitt would not have this remedy because he accrued his salary in 1947. The stock subscription theory should be applied to prevent such an inequity.

In Joy 1 Ifg. Co., 23 T.C. No. 137 (March 31, 1955), the Tax Court adopted a stod: subscription theory, holding neither Daggitt nor Macomber applicable where a corporation agreed to receive stock of its wholly owned subsidiary as payment of past and future engineering fees. Although the court put stress on the parent's accrual method of accounting. in holding the fees to be taxable income, the case is mainly distinguishable from Daggitt in the Government's argument for taxing the fees rather than the stock. The stock subscription rationale of $J o y$ should not be limited to accrual basis recipients. See note 27 supra.

29. See text at notes 16-23 supra. For possibilities of avoidance in future cases, see text at notes $41-43$ infra.

30. Commissioner v. Vandeveer, 114 F.2d 719 (6th Cir. 1940). See also note 4 supra and accompanying text.

31. See note 28 supra and text at notes 7-14 supra.

In the Daggitt case no move was made to reopen the 1947 return of Producers Transport, Inc., perhaps because the Commissioner considered that a stock subscription was involved and therefore no gain or loss recognized. See Letter from William H. Quealy, Esq., Counsel for Petitioners, to the Yale Law Journal, March 8, 1955, on file in Yale Law Library. However, it should be realized that if the amount of the obligation cancelled exceeds the amount used to subscribe for the stock, there may be income to the corporation on the cancellation of indebtedness. Commissioner v. Vandevecr, supra note 30 , at $722-23$. See text at note 53 infra.

The court could also have held that the majority stockholder, Daggitt, received all the stock and then made a gift of 100 shares to the minority stockholder, Reid, as the intention in giving Reid his additional compensation was primarily to keep his interest the same, 
The Tax Court, however, held that Eisner v. Macomber prevented realization of any income, even though the stock was distributed in payment of accrued salaries rather than as a dividend. ${ }^{32}$ If this view had been correct, the court could also have applied section 115(f)(1) of the Internal Revenue Code of 1939 exempting from taxation any corporate "distribution" of its stock to the extent that this does not "constitute income to the shareholder" under the Sixteenth Amendment. ${ }^{33}$ Although stock dividends generally involve capitalization of surplus, ${ }^{34} 115$ (f)(1)'s exemption of constitutionallyexempt dividends seems broad enough to include the distribution in Daggitt. ${ }^{35}$ Moreover, since the par value of the stock issued was equal to the salaries payable account cancelled, the stock distribution represented surplus made available by the salary cancellation despite the failure of Producers Transport to make a formal capitalization of surplus..$^{30}$

Section 305(a) of the Internal Revenue Code of 1954 grants tax exemption to "any distribution made by a corporation to its shareholders, with respect to the stock of such corporation," in stock of the corporation, even when this disturbs the proportional interest of existing shareholders. ${ }^{37}$ Since the phrase "with respect to the stock of such corporation" was intended

rather than to pay compensation. Deloss E. Daggitt, 23 T.C. No. 6, at 2 (Oct. 13, 1954). See Jacksonville Paper Co., P-H 1954 T.C. Mear. Dec. $\{54223$. See, also, note 69 injro. On this theory Daggitt would pay tax on the fair market value of the 1000 shares, as his proportionate interest was changed, and then pay a gift tax on the 100 shares given to Reid.

A third alternative would have been to hold that because the steclholders agreed at the time their salaries were voted to accept payment by a non-tasable stock distribution, see text at notes 16-19 and 25 supra, no salaries should have been deducted by the corporation or reported as income by the stockholders. See note $\$ 2$ infra. Cf. Natural Gasoline Corp. v. Commissioner, 219 F.2d $6 \$ 2$ (10th Cir. 1955).

32. See text at notes $25-26$ supra.

33. Int. Rev. Code of 1939, $\$ 115(f)(1), 53$ Stat. 47. Section 115(f) (1) was adopted in the Revenue Act of 1936, \& 115 (f) (1), 49 STAT. 1688, and was interpreted by the Supreme Court as making the pre-1936 stock dividend exemptions, including Eisner v: Macomber, 252 U.S. 189 (1920), exempt by statute. Helvering v. Griftuss, 318 U.S. 371 (1943).

34. See note 10 supra and accompanying text.

35. Although dividends occur only to the extent of current or accrued carnings and profits, Int Rev. Code of 1939, $\S \S 115(\mathrm{a})$, (b), as amended, 61 STuT. 179 (1947), 56 Stat. 896 (1942) (now INT. Rev. Cone of 1954, $\S 316$ ), earnings and profits are not

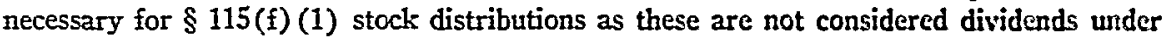
the code. See U.S. Treas. Reg. 118, § 39.115(a)-1(c) (1953).

36. The usual accounting procedure for the Daggilt transaction would have been to debit salaries payable and credit surplus and simultaneously to debit surplus and credit the capital stock account. In Daggitt no book entries were made affecting the surplus account, see note 21 sipra and accompanying text, but the effect on the surplus of the corporation was identical.

Regarding the weight to be given to a corporation's accounting pracedure in failing to make any capitalization in the course of stock distributions, conf are Bass $v$. Cummissioner, 129 F.2d 300 (1st Cir. 1942), with Adam A. Adams, 5 T.C. 351 (1945).

37. INT. Rev. CoDe of 1954, \& 305(a). See H.R. Rer. No. 1337, 83d Cong., 2d Sess. A81 (1954) ; S. Rep. No. 1622, 83d Cong., 2d Sess. 240-42 (1954). 
to make clear that this section exempted any distribution to stockholders by reason of their rights as "holders" of existing stock, it may mean that the section does not exempt a pro rata distribution to employees for accrued salaries. $^{38}$ Moreover, where a stock distribution "has the effect of the payment of compensation" for services rendered to the corporation, section 305(c) (3) refers to section 61 (a) (1), which includes such compensation within gross income. ${ }^{39}$ Although this cross reference has no legislative history and is intended to have no legal effect, ${ }^{40}$ it suggests a continuing congressional intent to tax stock distributions received as compensation. Congress apparently did not consider in 305(c) (3) the effect of pro rata stock distributions to employees. But, under the Tax Court's theory, Eisner $v$. Macomber would impose a constitutional prohibition against taxing these distributions, despite any attempt in the 1954 Code to subject them to taxation.

The Tax Court holding that the stockholder-employees in Daggitt received no taxable income indicates the possibility of substantial tax advantages for corporations which consider their stockholders as employees for the purpose of salary deductions but as investors for the purpose of stock distributions. Producers Transport eliminated the $\$ 10,000$ liability for accrued salaries by means of its stock distribution in 1948 without any diminution of assets. ${ }^{41}$ It still retained full control of the amount which it added to its capital account. ${ }^{42}$ Yet the corporation's taxable income for 1947 was reduced by the amount of the deduction for accrued salaries payable, thereby resulting in a tax saving of approximately $\$ 5700.43$ And under the Tax Court holding, cash basis employees would not be obligated to report the salaries or stock distribution as income. ${ }^{44}$ Therefore a tax advantage is inherent under Daggitt unless the Commissioner can either disallow the corporation's salary deduction or find a realization of income by the corporation when the liability for salaries is eliminated by the stock distribution.

The principal weapon to prevent the salary deduction is section 24 (c) of

38. H.R. REP. No. 1337, 83d Cong., 2d Sess. A81 (1954). This phrase was intended to exempt even stock distributions involving redemption or surrender of other stock. Ibid. Although the Senate made many changes in $\S 305$ of the House bill, see S. REp. No. 1622, 83d Cong., 2d Sess. 240-42 (1954), it neither changed nor commented upon this House provision.

39. INT. REv. CODE of 1954, §§ 305(c) (3), 61 (a) (1).

40. INT. REv. CODE of $1954, \S 7806$.

41. See text at note 19 supra.

42. Ballantine, Corporations 482-83 (rev. ed. 1946); see note 12 supra.

43. In 1947 Producers Transport, Inc., had $\$ 34,071.39$ of operating income before deducting the accrued salaries. Deloss E. Daggitt, 23 T.C. No. 6, at 2 (1954). The large tax saving was due to the jump in rates for corporate incomes above $\$ 25,000$. Int. Rev. Code of 1939, $\S \S 13,15$, as amended, 56 Stat. 805 (1942), 59 Stat. 568 (1945). The 1954 Code similarly has a jump in the corporate tax rate at $\$ 25,000$. INT. Rev. Cove of $1954, \S 11$.

44. See text at notes 24-26 supra. 
the 1939 Code, now section 267(a)(2) of the 1954 Code.45 This section prohibits a corporation from deducting expenses, including salaries, accrued to a stockholder who directly or indirectly owns more than fifty per cent in value of the stock of the corporation, ${ }^{40}$ if these expenses are not "paid" during the corporation's taxable year or $2 \frac{x}{2}$ months thereafter, and if they are not "includible" within the same period in the gross income of the stockholder. ${ }^{47}$

If the ninety per cent stockholder in Daggitt had been on the cash basis, the pro rata stock distribution would never have been includible in his gross income, because it did not constitute income. ${ }^{28}$ Therefore the salary would only be deductible if the stock distribution constituted payment. The cases construing section 24 (c) have indicated that a liability is not "paid" by a debtor corporation unless it produces taxable income to the creditor. 10 Any other interpretation would contravene the policy of $24(\mathrm{c})$ : to produce uniformity among related taxpayers, by preventing a corporate deduction without an accompanying inclusion of the same amount by the controlling stockholder. ${ }^{50}$ It therefore seems clear that corporate distribution of stock pro rata will not permit a salary deduction under $2+(\mathrm{c})$.

45. Int. Rev. Code of 1939, § 24(c), as amended, 67 St.1T. 617 (1953) (now I::T. REv. CODE of 1954, § 267 (a) (2)).

46. Int Rev. Code of 1939, $\$ 24$ (c) (3), 53 Stat. 17 (now INt. Rev. Cone of 1954, $\S 267(\mathrm{a})(2)(\mathrm{B}))$.

47. Int. Rev. Code of 1939, $\$ 24$ (c) (1), as amended, 67 Sr.sr. 617 (1953) (now INT. REV. CODE OF 1954, § 267 (a) (2) (A)).

48. See text at notes 25 and 32 supra. As Daggitt was on the accrual basis, his salary was includible in the year when his claim accrued. See text at note 52 infra.

49. Musselman Hub-Brake Co. v. Commissioner, 139 F.2d 65 (6th Cir. 1943); Michael Flynn Mifg. Co., 3 T.C. 932 (1944).

Prior to the 1953 amendment of 24(c) providing that a corporation could deduct expenses if "includible" within the specified period in the gross income of the related taxpayer, see note 47 supra and accompanying text, the principal problem concerning 24(c) was whether "payment" encompassed "constructive payment" so as to permit deduction of accruals to related taxpayers. Compare P.G. Lake, Inc. v. Commissioner, 148 F.2d 898 (5th Cir. 1945) (no payment of accrued interest set aside on books of corporation controlled by taxpayer having power to draw checks), with Anthony P. Miller, Inc. v. Commissioner, 164 F.2d 268 (3d Cir. 1947) (constructive payment of salary made by transfer of negotiable demand promissory notes, since recipient was obligated to report the notes as income). See Kaplan, Confusion in 24(c), 25 Taxis 152 (1947).

The 1953 amendment of $\S 24$ (c) (1), 67 STAT. 617, provides that either payment by the corporation or receipt by the related taxpayer within the taxable year of the corporation and two and one-half months is sufficient to allow the deduction.

50. Section 24 (c) was enacted to prevent a corporation and its controlling stocl:holders from advantageously selecting different years for the deduction and inclusion of the same item of compensation. See Paul, Some Problems Under the dicre Sceliuns 2f(c), 32 Taxes 191 (1954); H.R. Rep. No. 1546, 75th Cong., 1st Sess. 29 (1937). However, its purpose would be equally applicable where the stockholder necer was required to include the compensation as income. See H.R. REp., op. cit. supro. 
Section 24(c), however, is wholly inapplicable to a person, such as Reid, owning fifty per cent or less of the corporate stock, ${ }^{51}$ even though as a cash basis taxpayer he may never report his salary as income. Moreover, the policy of the section is satisfied in the case of an accrual basis stockholder, such as Daggitt, since the salary deducted by the corporation is includible within his gross income regardless of whether he receives payment. ${ }^{62}$ In both of these situations, the corporation can deduct reasonable compensation for stockholders.

The unwarranted tax advantages made possible by Daggitt would be eliminated if the corporation were held to realize income upon elimination of the salary liability. When a debt is settled for less than its face value, the debtor normally must report as taxable income the difference between the amount of the obligation and the amount of the settlement. ${ }^{53}$ But a discharge of indebtedness may be considered as a gift and not taxable to the debtor if the intent of the creditor was to forgive all or part of the claim without consideration, ${ }^{54}$ rather than to get the "best price available" from the debtor. ${ }^{\text {.5 }}$

A Treasury Regulation provides that when a shareholder in a corporation which is indebted to him "gratuitously forgives the debt" the transaction

51. See text at note 46 supra.

52. Int. Rev. Code of 1939, $\$ 24$ (c) (2), 53 Stat. 17 (now Int. Rev. Cone of 1954, $\S 267$ (a) (2)(B)). However, since there was an intent at the time the salary was accrued to "pay" the salary with a non-taxable stock distribution, see Deloss E. Daygitt, 23 T.C. No. 6 , at 2 (Oct. 13, 1954), it might be argued that the salary was not includible as income to the controlling stockholder, as he never should have accrued anything.

53. United States v. Kirby Lumber Co., 284 U.S. 1 (1931); Helvering v. Edison Bros. Stores, Inc., 133 F.2d 575 (8th Cir.), cert. denied, 319 U.S. 752 (1943); U.S. Treas. Reg. 118, $\$ 39.22$ (a)-13 (1953). However, if the debtor is insolvent, he receives no taxable income except the amount by which his assets exceed his liabilities as a result of the settlement. Texas Gas Distributing Co., 3 T.C. 57 (1944).

The debtor corporation has the option of reducing the basis of its property by the amount of the forgiveness, instead of reporting this amount as income. Int. Rev. Coulc of 1939 , $\$ 22(\mathrm{~b})(9)$, as amended, 64 Stat. 927 (1.950) (now INT. REv. ConE of 1954, $\S 108(a))$.

54. Helvering v. American Dental Co., 318 U.S. 322 (1942) (settlement of accrucd rent and interest on notes resulted in gratuitous forgiveness regardless of creditor's intent, since creditor received no consideration for the amount cancelled). A "gift" is not included within gross income. Int. Rev. Code of 1939 , $\$ 22$ (b) (3), as amended, 56 STAT. 809 (1942) (now INT. Rev. CoDE of 1954, $\S 102(a)$ ). However, "gift" may be cxempt from the income tax provisions without there being sufficient donative intent to subject the transfer to the gift tax. Holzman, Tax Classics: American Dental, 27 Taxes 379, 381 (1949).

55. See Commissioner v. Jacobson, 336 U.S. 28 (1949), where a debtor's purchase of bonds for less than face value resulted in income, since the bondholders bargaincd for the settlement and did not intend to release their claims as a gift. Jacobson's requirement of donative intent had the effect of overruling the mechanical forgivencss test laid down in American Dental, supra note 54. See Wright, Realizalion af Incomc Through Cancellations, Modifications and Bargain Purchases of Indebtedness, 49 MIICH. L. REv. 459, 474-77 (1951). 
usually results in a "contribution to the capital of the corporation to the extent of the principal of the debt." 50 Although this might imply that forgiveness of a non-principal indebtedness produces income to the corporation, some courts have interpreted the regulation to mean that a stockholder's gratuitous cancellation of any corporate debt owed him, including accrued salaries and interest, results in no income. ${ }^{57}$ But the Eighth Circuit, in $\mathrm{Hol}$ vering $v$. Jane Holding Corp., ${ }^{58}$ noting the prior saving by the corporation when these expenses were deducted, considered the regulation applicable only to the forgiveness of "principal" indebtedness such as loans to the corporation, where there had been no previous tax benefit." It held that the discharge by the sole stockholder of a claim for accrued interest on a loan resulted in income to the corporation. ${ }^{\text {co }}$

"Principal" as used in the regulation apparently refers to the principal amount of a debt, as differentiated from interest, and does not seem to distinguish between deductible and non-deductible debts. ${ }^{61}$ However, the tax

56. U.S. Treas. Reg. 118, $\S 39.22(a)-13$ (1953). Since a contribution to capital results from any forgiveness of indebtedness by a shareholder, Commissioner $v$. Vandeveer, 114 F.2d 719 (6th Cir. 1940), the regulation merely indicates that a gratuitous forgiveness of a principal debt does not produce income. Even if the forgiveness is a contribution to capital, its basis may be zero if the creditor never valued his claim fur income tax purposes. George Hall Corp. v. Shaughnessy, 67 F. Supp. 748 (N.D.X.Y. 1946) ; Brazoria Investment Corp., 20 T.C. 690 (1953). Of course, unless a cancellation of indebtedness is involved, a contribution to capital results in no income to the corporation. See note $2 S$ supra.

If the forgiveness is a contribution to capital, the transaction will usually not be considered a gift unless the capital contributions are not proportiunate to sharcholdings. See Dunham, How to Elinimate the Tax ort Debt Concellation, 2y Taxes 127, 129-31 (1951). See also note 54 supra and note 65 infra.

See, generally, Lebowitz, Forgizeness of a Debt Owed to a Shareholder-Creditor, 27 TAXES 897 (1947).

57. Commissioner v. Auto Strop Safety Razor Co., 74 F.2d 226 (2d Cir. 1934) (royalties, loans, interest); Carroll-MIcCreary Co. v. Commissioner, 124 F.2d 303 (2d Cir. 1941) (salaries). Although these cases stated that the debtor's tax advantages from the prior deduction of the cancelled debts were immaterial, they were decided on facts occurring prior to the change in the regulation adding "to the extent of the principal of the debt." See text at note 56 supra.

58. 109 F.2d 933 (Sth Cir.), cert. denicd, 310 U.S. 653 (1940).

59. Helvering v. Jane Holding Corp., 109 F.2d 933, 939 (Sth Cir.), cerl. denied, 310 U.S. 653 (1940). The facts in Jane also occurred prior to the change in the regulation. See note 57 supra.

60. Helvering v. Jane Holding Corp., 109 F.2d 933, 944 (8th Cir.), ccrt. desicd, 310 U.S. 653 (1940). Jane was undercut by the Supreme Court's decision in Americans Dental which impliedly rejected the tax benefit doctrine. Helvering v. American Dental Co., 318 U.S. 322, 328 (1942). However, the limitation of American Dealal by Commissioner v. Jacobson, 336 U.S. $2 S$ (1949), apparently renews the force of Jane. Sce note 55 supra. For support of Jane see Warren \& Sugarman, Canccllation of $\mathrm{Jn}$ debtedness and Iis Tax Consequences, 40 CoLuar. L. Rev. 1326, 1359-61 (1940).

61. See Helvering v. Jane Holding Corp., 109 F.2d 933, 939 n.1 (Sth Cir. 144u. See also Wright, supra note 55 , at 468 n.1. 
benefit to the corporation from the deduction of the principal amount of a salary debt is identical to that resulting from deduction of interest. Therefore the cases extending the Jane rationale to a stockholder's forgiveness of a salary claim seem justified. ${ }^{62}$

Despite the possible limiting effect of the regulation, forgiveness of even a salary claim may not produce income to the corporation if a stockholder's intent in fact is to make a gift. $^{63}$ Donative intent might seem particularly clear in a case such as Daggitt where the controlling stockholders received no consideration for cancellation of their salary claims, since, under the Tax Court reasoning, the stock distribution did not result in any income to them..$^{04}$ Yet where all the shareholders of a corporation participate in a proportionate forgiveness of these accrued corporate liabilities, it seems unreasonable to conclude that they are making gifts, because the "forgiveness" merely increases the value of their proportionate interests in their own corporation. ${ }^{65}$ Even if the controlled corporation is regarded as an entity distinct from its stockholders, both the tax benefit resulting from the prior deduction of the salary claims and the improved capital position of the corporation resulting from the debt cancellation provide sufficient consideration for the forgiveness.00 Proportionate forgiveness of accrued salaries should therefore result in income to the corporation to the extent of the deduction previously taken in the year of salary accrual.

The stock distribution in Daggitt provides an opportunity for the Commissioner to find a realization of income to the corporation by the discharge of indebtedness. However, if the stockholders were willing to forego payment of salaries and the corporation did not need to obtain a forgiveness of the salary claims, the corporation over a substantial period of years could deduct sums designated as compensation but actually intencled merely to re-

62. See, e.g., Amsco-Wire Products Corp., 44 B.T.A. 717 (1941); Beacon Auto Stores, Inc., 42 B.T.A. 703 (1.940).

63. See Commissioner v. Jacobson, 336 U.S. 28, 50 (1949).

64. See text at note 25 supra.

65. Compare Robert H. Scanlon, 42 B.T.A. 997 (1940) (transfer of stock to carporation by sole stockholder not subject to gift tax), zerith Frank B. Thompson, 42 B.T.A. 121 (1940) (transfer of stock to corporation by one of controlling shareholders subject to gift tax). See Dunham, supra note 56. See also notes 54 and 56 supra.

66. Cf. Helvering v. Jane Holding Corp., 109 F.2d 933 (8th Cir.), cert. denicd, 310 U.S. 653 (1940) (improvement of corporation's asset position sufficient consideration); Howard Paper Co., 43 B.T.A. 545 (1941) (same). But ef. Commissioner v. Auto Strop Safety Razor Co., 74 F.2d 226 (2d Cir. 1934) (improved capital position of corporation indicates, capital contribution rather than income). But sec note 56 supra.

The above criteria for finding consideration in cases involving pro rata forgiveness where non-taxable stock is received seem equally applicable to cases in which a controlling shareholder forgives a debt without receiving anything in return, since the corporation is his instrumentality. However, if a small sharcholder forgives a debt, it is more likely that such a forgiveness is gratuitous since the benefits to the corporation from his forgiveness do not accrue to him as directly as they would to a controlling shareholder. 
duce the corporation's tax liability. ${ }^{\text {or }}$ But many closely-held corporations may need to obtain additional capital by means of loans, and will have to arrange some transaction eliminating this liability in order to improve their credit position. 68 Moreover, the Commissioner may disallow these accruals on the theory that a corporation may deduct reasonable amounts for compensation only if it actually intends to pay them. ${ }^{09}$ If the Commissioner cannot determine the true nature of any salary transaction between the corporation and its controlling stockholders, Daggitt may point the way to tax manipulation by means of the corporate personality.

67. See, e.g., Beacon Auto Stores, Inc., 42 B.T.A. 703 (1941). Since most employees would be on the cash basis, they would never report this as income. But if the stockholder-employee owned more than fifty per cent of the stock of the corporation and was not on the accrual basis, section 24 (c) would prohibit the salary deduction. See text at notes $48-51$ supra.

68. See, e.g., Midland Tailors, P-H 1943 T.C. Afem. Dec. If 43292; Tanner Mffg. Co., P-H 1943 T.C. Mem. Dec. If 43299. Before cancelling his claim, the stoclsholder will probably try to achieve the same results by subordinating it. See Alidland Tailors, supra.

69. Beacon Auto Stores, Inc., 42 B.T.A. 703 (1941); Holmes \& Janes, Inc., 30 B.T.A. 74 (1934). In Jacksonville Paper Co., P-H 1954 T.C. Afem. Dec. II 54223, stod: issued by a close corporation as payment for accrued salaries was redistributed by the stockholders in proportion to their holdings. The substantial part of the salary deduetion was disallowed not because the salaries were unreasonable, but because the corporation never intended to pay the salaries as accrued. Cf. Baldwin Bros. Co., P-H 1945 T.C. Mem. Dec. If 45262, aff'd, 157 F.2d 517 (6th Cir. 1946), in which salaries were held unreasonable because the corporation was not in a position to pay such salaries. Also cf. Regensburg v. Commissioner, 144 F.2d 41 (2d Cir.), ccrl. dcricd, 323 U.S. 783 (1944), in which the court held that "loans" received by stochholders from their corporation were in fact dividends, noting the large amount of the loans in comparison to the assets of the corporation.

The Commissioner has also succeeded in having the debtor report as income the amount of obligations on which the statute of limitations has run. Securities $C_{0}$. v. United States, 85 F. Supp. 532 (S.D.N.Y. 1948). Cf. R. O'Dell \& Sons Co. v. Commissioner, 169 F.2d 247 (3d Cir. 1948). Although these cases were based on a cancellation of indebtedness doctrine, they amount to a declaration by the courts that there no longer is an intent by the debtor to pay his creditors. 